ПАРЛАМЕНТСЬКИЙ КОНТРОЛЬ ЯК ОСНОВА ЦИВІЛЬНОГО КОНТРОЛЮ НАД СЕКТОРОМ БЕЗПЕКИ ТА ОБОРОНИ ДЕРЖАВИ

\title{
PARLIAMENTARY CONTROL AS THE BASIS OF CIVIL CONTROL OVER THE SECURITY AND DEFENSE SECTOR OF THE STATE
}

У статті проведено аналіз останніх досліджень із проблематики парламентського контролю як одного із складників демократичного цивільного контролю над силовими структурами держави, як важливого інституту національної безпеки. Автор розкриває сутність поняття силових спеціальних структур держави та особливості парламентського контролю як основи демократичного цивільного контролю над структурами безпеки і оборони держави. При цьому парламентський контроль над сорерою безпеки і оборони розглядається як сукупність контрольних та керівних заходів, які здійснюються відповідно до Конститу ції України із залученням представницьких державних органів (разом із громадськими організаціями), спрямованих на здійснення контролю за виконанням положень оборонної доктрини держави, воєнної політики, за оптимальними і раціональними витратами бюджетних коштів, дотриманням прав $i$ свобод військовослужбовців, цивільних фрахівців, їх соціально-правового захисту з метою ефективного фуунціонування усієї системи оборони країни. Акцентовано увагу на тому, що якраз на парламент покладена основна місія демократичного цивільного контролю над сектором безпеки і оборони держави, який він сам створює, призначає керівничтво і контролює їхню діяльність. Ефективність його здійснення безпосередньо впливає на стан національної безпеки в Україні та реалізацію основних фрункцій держави. у статmі узагальнено думку науковців про демократичний цивільний контроль за сектором безпеки і оборони держави у демократичному суспільстві як стримуючий механізм від можливості військового перевороту, встановлення недемократичного режиму «хунти», іншої узурпації влади, втручання в політичний прочес країни із зовні та прихованої («гібридної») чи відкритої агресії, а також $\epsilon$ свого роду каталізатором громадського контролю. Наголошено на важливості розуміння і виокремленні межі втручання недержавних структур $i$ «сфрери дотику» - щоб їхні дії не загрожували національній безпеці. Ключові слова: сектор безпеки і оборони, парламентський контроль, демократичний цивільний контроль, парламент, держава, функції держави, Європейське співтовариство, HATO.

The article analyzes recent research on parliamentary control as one of the components of democratic civilian control over the security forces of the state, as an important institution of national security. The author reveals the essence of the notion of power and special structures of the state and peculiarities of parliamentary control as the basis of democratic civil control over the structures of security and defense of the state. At the same time, parliamentary control over the sphere of security and defense is considered as a set of control and management measures, which are carried out in accordance with the Constitution of Ukraine with the involvement of representative state bodies (together with public organizations), aimed at exercising control over the implementation of the state defense doctrine, military policy, optimal and rational spending of budgetary funds, observance of the rights and freedoms of servicemen, civilians, their social and legal protection in order to effect of the entire country's defense system. Attention is drawn to the fact that it is the Parliament that has the primary mission of democratic civilian control over the security and defense sector of the state, which it creates, appoints leadership and controls their activities. The effectiveness of its implementation directly affects the state of national security in Ukraine and the implementation of the main functions of the state. The article summarizes the opinion of scientists about democratic civil control over the security and defense sector of the state in a democratic society as a restraining mechanism against the possibility of a military coup, establishment of a democratic regime of the junta, other usurpation of power, interference in the political process of the country from outside and hidden) or overt aggression, and is a kind of catalyst for public control. The importance of understanding and isolating the limits of intervention by non-state actors and the "sphere of touch" is emphasized - so that their actions do not threaten national security.

Key words: parliamentary control, civil control, parliament, state, functions of the state, European community, NATO. Інститут підготовки кадрів Державної служби зайнятості України

Постановка проблеми в загальному вигляді. Перспективи входження України до ЄС та у військовий союз НАТО передбачає використання демократичних механізмів контролю над сектором безпеки і оборони (далі - СБіО), що включає силові та спеціальні структур и держави з метою збереження позицій демократичного управління і як засторогу від тоталітаризму. Але Україна не має достатнього досвіду використання елементів та й системи такого контролю, який часто науковці та практики державного управління називають «цивільним», адже питання демократичного цивільного контролю (далі - ДЦК) над армією, міліцією, КДБ у Радянському Союзі зазвичай не піднімалося, оскільки вважалося, що «народ і армія єдині», а в сутності ці структури контролювались ЦК КПРС та Компартіями так званих союзних республік. За часів тоталітаризму - панування радянської влади, а по суті Компартійної диктатури, цікавість і намагання впровадження народного контролю в інституціональній формі (наприклад, діяльність комітетів «Солдатських матерів», спілок ветеранів 
тощо) до війська здебільшого засуджувалося, або просто ігнорувалося. Тому з радянського минулого Україна не має досвіду цивільного контролю військових (силових структур) формувань держави. Він почав сформуватись і проявлятись лише в новітню добу української державності. Хоча в окремі періоди становлення Української державності певний контроль був, особливо за часів Гетьманщини та УНР. Для розробки ефективних механізмів запровадження і розвитку цивільного контролю над СБіО держави варто провести не лише дослідження зарубіжного досвіду але й вивчити наші тематичні історичні уроки 3 минулого державного будівництва.

Аналіз останніх досліджень і публікацій. Тематика дослідження ДЦК над СБіО держави $€$ досить актуальною, і їй присвячено наукові праці багатьох науковців і практиків. Серед них - Л. Пашко [1], Л. Хомічак [1], П. Ворона [2; 3], О. Гриненко [4], М. Дєнєжкін [4], Н. Плахотнюк [7], В. Смолянюка [8], Г. Ситник [9], М. Теплюк [10], М. Требін [11], М. Утяшев [12], А. Корнілаєва [12], Н. Череміскіна [13] та інші. Але в їх роботах основна уваги приділена лише аналізу механізмів цивільного контролю і як рекомендації використовуються типові його моделі у європейських країнах. Тому тематика дослідження механізмів ДЦК потребує постійних наукових пошуків та досліджень.

Мета статті - аналіз останніх досліджень із проблематики парламентського контролю, як однієї з складових цивільного контролю над силовими структурами держави та елементу національної безпеки.

Виклад основного матеріалу. 3 початку незалежності Українська держава перед світовим товариством взяла на себе міжнародні зобов'язання встановити ДЦК над сектором безпеки і оборони держави. Зокрема про це йдеться у таких документах, як «Партнерство заради миру: Рамковий документ», «Хартія про особливе партнерство між Україною та НАTO», а також «Кодекс поведінки стосовно воєнно-політичних аспектів безпеки», затверджений на Будапештському саміті ОБСЄ у 1994 році. Сьогодні контроль над Збройними Силами України (ЗСУ) є важливим елементом системи військово-цивільних відносин та ключовим у стабілізації політичного життя країни. Серед основних функцій держави виокремлюємо внутрішні та зовнішні. До внутрішніх функцій належать: державне регулювання економіки, соціальна, культурно-виховна, охорона громадського порядку, захист існуючого суспільного ладу від внутрішніх деструктивних сил тощо.
До зовнішніх функцій належать: захист країни від зовнішньої агресії, захист державних інтересів на міжнародній арені за допомогою дипломатичної діяльності, розвиток співробітництва з іншими країнами світу тощо.

Для реалізації функцій держава створює спеціальні органи, які в сукупності утворюють структуру держави. Варто більш детально розглянути саме поняття силові та спеціальні структури держави. До структури держави входять: органи державної влади - законодавчої і виконавчої; органи охорони правопорядку та органи правосуддя (міліція, внутрішні війська, суд, прокуратура); органи, що забезпечують внутрішню безпеку країни (СБУ - служба безпеки України) та органи, що забезпечують зовнішню безпеку країни (армія, управління зовнішньої розвідки, митна служба, прикордонна служба). Останні другий, третій і четвертий елементи наведеної структури держави $€$ так звані силові відомства і міністерства або силові та спеціальні структури держави. Всі вони входять в СБіО держави. Силові відомства і міністерства виділяються зі структури виконавчої влади в якості самостійних елементів держави на підставі їх особливої значущості для виконання основних функцій держави.

Одним з головних офіційних механізмів ДЦК над СБіО держави $€$ парламентський контроль. Дослідженню парламентського контролю як одній із провідних функцій українського парламенту присвячена наукова праця Н. Плахотнюк «Контроль як провідна функція українського парламенту (організаційний аспект)» у якій автор зазначає, що «...важливим моментом становлення парламентаризму $€$ реалізація Верховною Радою України (ВРУ) контрольної функції. Це пов'язано з тим, що ця функція значною мірою опосередковує відносини між законодавчою і виконавчою владою. Український парламент має навчитися здійснювати контрольну функцію щодо органів виконавчої влади прозоро, ефективно та комплексно» $[7$, с. 441].

Парламентський контроль визначається як «...важлива функція ВРУ, що здійснюється безпосередньо парламентом, а також його органами, посадовими особами, народними депутатами України та спеціалізованими допоміжними інституціями - Уповноваженим ВРУ $з$ прав людини і Рахунковою палатою та спрямована на перевірку законності, ефективності й доцільності дій і рішень органів і посадових осіб державної влади, місцевого самоврядування, підприємств, установ та організацій, 3 метою виправлення виявлених недоліків та недопущення їх у подальшому» [1, с. 163-164]. 
Автори М. Утяшев і О. Корнілаєва дають визначення парламентському контролю як «комплексу різних заходів, що здійснюються вищим законодавчим (представницьким) органом державної влади щодо постійного нагляду й перевірки діяльності системи, а також щодо усунення виявлених в результаті такої перевірки порушень і попередження можливих невідповідностей» [12, с. 30].

Нині, особливо після Революції гідності, коло активних учасників парламентського контролю різко розширюється, й до нього вже варто відносити ті об'єднання громадян, політичні партії, засоби масової інформації й конкретних громадян України, які зацікавлені в самому процесі й наслідках контролю. Підконтрольними об'єктами виступають органи державного управління, органи місцевого самоврядування та їх посадові особи, а також органи, підприємства, організації, установи, які створені в Україні або діють в межах її інтересів за кордоном. Громадяни України, а точніше їх права і обов'язки, також $€$ об'єктами парламентського контролю.

Парламентський контроль над сферою безпеки і оборони - це сукупність контрольних та керівних заходів, які здійснюються відповідно до Конституції із залученням представницьких державних органів (разом із громадськими організаціями), спрямованих на здійснення контролю за виконанням положень оборонної доктрини держави, воєнної політики, за оптимальними і раціональними витратами бюджетних коштів, дотриманням прав і свобод військовослужбовців і цивільних фахівців, їх соціально-правового захисту з метою ефективного функціонування усієї системи оборони країни [11].

Встановлення та здійснення парламентського контролю за сферою безпеки й оборони $€$ невід'ємною складовою процесів демократизації усього суспільства, важливий чинник регулювання цивільно-військових відносин, необхідна умова для європейської та євроатлантичної інтеграції. Варто відзначити значний інтерес науковців до проблем контролю за оборонною сферою, i, зокрема, до специфіки здійснення ДЦК (невід'ємною складовою якого $є$ парламентський контроль). Вітчизняні науковці П. Ворона [2; 3], О. Гриненко [4], Г. Ситник [9], В. Смолянюк [8], М. Требін [11], Н. Череміскіна [12] обґрунтували доцільність встановлення ДЦК, проаналізували специфіку його реалізації, розглянули правові засади організації, механізми здійснення. Питання реалізації функції парламентського контролю розглядаються у науковій статті М. Теплюка. Автором зазначено, що парламентський кон- троль може мати різний обсяг залежно від форми правління в державі, а також державотворчих традицій. Наголошено, що найбільш сильний парламентський контроль притаманний державам 3 парламентською формою правління та окреслено основні проблеми на шляху до посилення системи парламентського контролю в Україні, зокрема: «...парламентський контроль в існуючих умовах поділу влади, будучи одним із механізмів «стримувань і противаг» між гілками влади, не передбачає прямого втручання парламенту в безпосередню діяльність глави держави, державних органів. у демократичних державах парламентський контроль $€$ механізмом реальної політики, у той час як в умовах авторитарних контрольні повноваження парламентів, по суті, виявляються фіктивними» $[10$, c. 463$]$.

В українських реаліях, незважаючи на щорічні Послання Президента України ВРУ та періодичну звітність перед нею керівників силових структур, професор Г. Ситник у підручнику «Державне управління у сфері національної безпеки (концептуальні та організаційно-правові засади)» [9, с. 363-364], зазначив, що за європейськими стандартами парламентський контроль над СБіО є повноцінним, коли під час його законодавчих ініціатив постійно перебувають 5 основних напрямів управлінської діяльності безпекових та оборонних структур: політика, особовий склад (персонал), фінанси, діяльність, матеріально-технічне оснащення.

Перший напрям це право парламенту розглядати і затверджувати базові нормативно-правові акти: концепції, стратегії, державні програми. В Законі України «Про демократичний цивільний контроль над Воєнною організацією і правоохоронними органами держави» така норма звужена до державних програм реформування і розвитку ЗСУ.

Другий напрям - це повноваження парламенту затверджувати план: управління людськими ресурсами (в тому числі й спосіб комплектування сил безпеки та оборони); чисельність особового складу всіх складових безпекового сектору держави; схвалювати призначення вищих військових керівників. В Україні ці повноваження обмежуються тільки законодавчим затвердженням чисельності особового складу СБіО країни, як правило, без участі в обговоренні з громадськістю та незалежними експертами і науково не обґрунтовані.

Третій напрям - це контроль над державним бюджетом. Важливою також залишається проблема вдосконалення бюджетного контролю 
над СБіО з боку ВРУ, де на окрему увагу заслуговує формування видатків для фінансування програм закупівлі основних видів озброєння і техніки та, що найголовніше, їх обов'язкове виділення протягом відповідного бюджетного періоду. Йдеться про так звані захищенні статті у державному бюджеті країни.

Четвертий напрям - це право парламенту на розслідування у випадку помилкової або невдалої діяльності виконавчої влади. В діяльності українського парламенту практики такого контролю, на жаль, немає.

П'ятий напрям передбачає причетність парламенту до питань матеріально-технічного переоснащення силового сегменту держави на рівні уточнення потреб у новому оснащенні та урядових рішень відносно контрактів щодо закупівлі і продажу [1]. Контроль з боку парламенту спирається, насамперед, на конституційні повноваження ВРУ, які визначені статтею 85 Конституції [7]. Загалом, ВРУ визначає політику і основи нацбезпеки; визначає структуру, чисельність, функції та бюджети (постатейно) ЗСу та інших збройних формувань; визначає основи правового і соціального захисту військовослужбовців; затверджує на посаді міністра оборони; розглядає стан і доцільність використання бюджетних коштів виділених на потреби національної оборони; визначає порядок збереження державної таємниці при інформуванні громадян про діяльність військової організації; визначає правовий режим державного кордону; визначає правовий режим воєнного і надзвичайного стану і затверджує укази президента про введення надзвичайного та воєнного стану і про мобілізацію; оголошує за поданням президента стан війни і миру і схвалює рішення президента про використання ЗСУ та інших військових формувань у разі збройної агресії; схвалює рішення про надання військової допомоги іншим державам і направлення підрозділів ЗСУ до інших держав; дає згоду про обов'язковість міжнародних договорів України які стосуються воєнної організації.

У здійсненні контрольних функцій ВРУ її можливості підсилюють Рахункова палата України в частині контролю за використанням бюджету і Уповноважений ВР з прав людини в частині контролю за дотриманням прав людини. Рахункова палата як орган контролю з боку ВРУ діє на підставі статті 98 Конституції і відповідного закону про Рахункову палату. Її завдання - контроль за надходженням коштів до бюджету і за їх використанням. Рахункова палата має доступ до всіх без винятку документів, що стосуються використання бюджетних грошей, зокрема і секретним. Рахункова палата регулярно звітує ВРу і Президенту про результати контролю (аудиту), аналізує для ВРУ проект закону про державний бюджет, щоквартально інформує ВРУ про стан виконання закону про держбюджет і подає пропозиції щодо усунення виявлених недоліків. Глава і 8 членів Рахункової палати призначаються Верховною Радою України.

Уповноважений ВРУ з прав людини (омбудсмен) теж є суб'єктом контролю з боку ВРУ за збройними силами та іншими збройними формуваннями. Він діє на підставі статті 101 Конституції України та відповідного законупро уповноваженого ВРУ зправ людини. Омбудсмен здійснює контроль за дотриманням конституційних прав і свобод людини. Ці питання особливо важливі в контексті діяльності збройних формувань, які реалізують право держави на насильство. Уповноважений призначається на посаду ВРУ шляхом таємного голосування строком на п'ять років і його повноваження не можуть бути припинені раніше цього терміну ні під час розпуску ВРУ, ні під час уведення воєнного чи надзвичайного стану. Омбудсмен діє незалежно, має імунітет і відповідні повноваження. Він має право бути негайно прийнятим будь-яким представником державної влади, зокрема Президентом і Главою ВРУ, може отримати доступ до будьяких документів, навіть секретних, і на будьякий об'єкт (військову частину) та на будьякий захід. Омбудсмен робить щорічний звіт ВРУ про стан захисту прав людини в Україні, а так само може робити за потреби спеціальні доповіді.

Найбільш діючою функцією впливу з боку BPу $€$ законотворча функція. Рада приймає закони, що стосуються національної оборони і використання збройних сил, військових формувань і у такий спосіб контролює їх. Однак якість цих законів часто виявляється незадовільним. Перш за все це обумовлено недостатньою компетентністю народних депутатів в питаннях забезпечення національної безпеки і оборони. Консультативну допомогу в здійсненні своїх функцій повинні їм надавати як штатні радники ВРУ, так і свої власні експерти. Основним комітетом ВРУ, відповідальним за безпосередній контроль за сектором безпеки та оборони є парламентський Комітет із питань національної безпеки і оборони. До повноважень Комітету входять такі питання: національна безпека України; правовий режим державного кордону, воєнного і надзвичайного стану; оборонно-промисловий комплекс, державна система страхового фонду документації, військове та військово-технічне співробітництво України з іншими державами, 
а також її участь в міжнародних миротворчих операціях; державна політика в сфері оборони; боротьба з тероризмом; здійснення, зокрема парламентського, контролю над Воєнною організацією держави; військова служба, ЗСУ та питання їхнього реформування; військові формування, створені відповідно до Зу; альтернативна (невійськова) служба; соціально-правовий захист військовослужбовців та членів їхніх сімей; військова наука і освіта; державна система спеціального зв'язку.

У складі комітету створено 5 підкомітетів: із питань військової безпеки і оборони; з питань військово-промислового комплексу та військово-технічного співробітництва; з питань соціального і правового захисту військовослужбовців та членів їх сімей; із питань державної безпеки; з питань безпеки державних інформаційних систем; із питань ефективності використання бюджетних коштів. Також окремі контрольні функції щодо сектору безпеки та оборони можуть здійснювати в частині своєї компетенції Комітет з питань бюджету (підкомітет із питань державного фінансового контролю та діяльності Рахункової палати), Комітет у закордонних справах, Комітет у справах ветеранів, учасників бойових дій, учасників антитерористичної операції і людей з інвалідністю, Комітет із питань запобігання корупції. Комітети на своїх засіданнях аналізують законопроєкти і хід виконання вже ухвалених законів і постанов у сфері національної безпеки і оборони; вносять на розгляд ВРУ, Президента, Кабінету Міністрів пропозиції щодо усунення виявлених проблем.

Усі народні депутати отримують доступ до державної таємниці автоматично при входженні на посаду без оформлення допуску. Відповідно до законодавства про статус народного депутата члени Комітету з питань національної безпеки і оборони для отримання інформації щодо діяльності ЗСУ і інших збройних формувань роблять депутатські запити і депутатські звернення. Також депутати мають право безперешкодного відвідування будьякого об'єкта (органу або підприємства) незалежно від ступеня його закритості (режиму секретності). Для розслідування питань, що становлять суспільний інтерес, у ВРУ може бути створена тимчасова слідча комісія.

Отже, місце парламентського контролю в системі державного управління зумовлено статусом суб'єкта контролю - представницького органу держави. Це дає підстави для визначення парламентського контролю як вищої форми контрольної діяльності в державі, яка виходить за межі державного контролю як функції державного управління.
Сьогодні межі парламентського контролю в системі державного управління закінчуються там, де починаються повноваження оперативної й виконавчо-розпорядчої діяльності, а також повноваження судової влади щодо здійснення правосуддя, втручатися у які відповідно до принципу поділу влади законодавча влада не має права.

Відповідно, сутність парламентського контролю полягає у здійсненні комплексу заходів щодо забезпечення законності в діяльності органів виконавчої влади, аналізі практики реалізації законодавства, а також досягненні злагодженої роботи державного механізму й запобіганні порушенням прав і свобод людини і громадянина. Парламентський контроль залишається слабким і малоефективним. Парламент може впливати лише на призначення міністра оборони і міністра внутрішніх справ та Голови СБУ, хоча, після їхпризначення, системного контролю за ними вже немає. А на призначення їх заступників, а також керівників служб та інших військових формувань український парламент впливу не має взагалі. Комітету ВРУ з питань розвідки до цього часу не створено, системно контролювати розвідувальні органи та системно лобіювати інтереси розвідників Служби зовнішньої розвідки, Головного управління розвідки Міністерства оборони та інших відомств у ВРУ немає кому.

Питання призначення цивільного керівництва міністерства оборони черговий раз планується на майбутнє. Отже, зберігається тенденція неготовності демократично обраних політиків брати на себе безпосередню відповідальність за керівництво обороною країни. При цьому, СОБ визначає, що: «Для узгодження $з$ євроатлантичними нормами та стандартами до кінця 2018 року Україна посилить цивільний контроль над ЗСУ через Міністра оборони України та Міністерство оборони України, в тому числі шляхом призначення цивільних Міністра оборони, його заступників та Державного секретаря Міністерства оборони України».

Парламентський контроль повинен здійснюватися в напрямі вирішення в державі таких основних завдань: недопущення та припинення порушень Конституції, законів України, інших нормативно-правових актів, регламентуючих застосування 3Су; доведення органам державної влади та громадським інститутам суспільства повної, достовірної та оперативної інформації про відповідність Конституції стану та діяльності ЗСУ; створення законодавче визначеного механізму цивільно-військових відносин щодо забезпечення пріоритетів політичних підходів з питань військового 
будівництва та розвитку, а також у прийняті рішень використання військових формувань; збалансованість економічних можливостей держави, бюджетних асигнувань на оборону та реальних потреб військових формувань для надійного забезпечення оборони країни; підтримка політичної стабільності українського суспільства в напрямі невтручання, виключення можливості застосування військових формувань у суспільно-політичних процесах; урахування пропозицій, громадської думки з питань діяльності військового управління та посадових осіб у сфері оборони країни, а також з питань захисту соціальних, економічних, політичних та особистих прав і інтересів військовослужбовців, цивільного персоналу.

Висновки. Наголошуємо, що якраз на парламент покладена основна місія ДЦК над СБіО держави які він створює, призначає керівництво і контролює їхню діяльність. Ефективність його здійснення безпосередньо впливає на стан національної безпеки в Україні та реалізація основних функцій держави. Адже якраз ці структури реалізовують антикорупційну політику, яка сприяє або паралізує здійснення інших функцій. На думку науковців, ДЦК над СБіО держави у демократичному суспільстві є стримуючим механізмом від можливості військового перевороту, встановлення недемократичного режиму «хунти», іншої узурпації влади, втручання в політичний процес країни ззовні та прихованої (гібридної) чи відкритої агресії, а також є свого роду поштовхом для громадського контролю, але варто знати межі втручання недержавних структур і «сфери дотику» - щоб їхні дії не загрожували національній безпеці.

\section{ЛІТЕРАТУРА:}

1. Адміністративна процедура та контроль за діяльністю адміністративних органів в Угорщині, Польщі, Болгарії, Естонії та Албанії / пер. 3 фрр. Л.А. Пашко, Л.А. Хомічак. Київ : Вид-во УАДУ, 1999. 236 с.

2. Ворона П.В. Інститут цивільного контролю над силовими структурами держави як фактор євроатлантичної інтеграції. Актуальні проблеми європейської та євроатлантичної інтеграції : матеріали 15-ї регіон. наук.-практ. конф., м. Дніпро, 17 травня 2018 р. / за наук. ред. Л.Л. Прокопенка. Дніпро : ДРІДУ НАДУ, 2018. С. 248-252.

3. Ворона П.В. Цивільний контроль над силовими структурами держави: проблематика співвідношення політики та управління. Взаємозв'язок політики і управління: теоретичний і прикладний аспект : матеріали круглого столу / за заг. ред. О.Б. Кірєєвої. Дніпро : ДРІДУ НАДУ, 2018. С. 29-34.

4. Гриненко О.І., Дєнєжкін М.М. Проблеми формування цивільно-військових відносин в Україні. Наука і оборона. 2002. № 2 С. 36-40.

5. Демократичний цивільний контроль у світі. Проектний Офріс Рефрорм Міністерства оборони України. URL: http://civilian.defense-reforms.in.ua.

6. Конституція України: прийнята на п'ятій сесії Верховної Ради України 28 червня 1996 р. URL: http:// zakon.rada.gov.ua.

7. Плахотнюк Н.Г. Контроль як провідна фрункція українського парламенту (організаційний аспект). Парламентаризм в Україні: теорія та практика : матеріали Міжнар. наук.-практ. конф., присвяч. 10-й річниці 3 дня проголошення незалежності України, м. Київ, 26 червня 2001р. / Верховна Рада України ; Ін-т законодавства. Київ, 2001. С. 441-446.

8. Політологія : підручник для курсантів вищих військових навчальних закладів Збройних Сил України / за заг. ред. В.Ф. Смолянюка. 1-е вид. Вінниця : Нова книга, 2002. 446 с.

9. Ситник Г.П. Державне управління у сорері національної безпеки (концептуальні та організаційно-правові засади) : підручник. Київ : НАДУ, 2012. 544 с., С. 363-364.

10. Теплюк М.О. Парламентський контроль - одна 3 основних функцій парламенту України. Парламентаризм в Україні: теорія та практика : матеріали Міжнар. наук.-практ. конфр., присвяч. 10-й річниці з дня проголошення незалежності України, м. Київ, 26 червня 2001 р. / Верховна Рада України ; Ін-т законодавства. Київ, 2001. С. 463-468.

11. Требін М.П. Армія та суспільство: соціально-фрілософський аналіз взаємодії в умовах трансорормації : монографія. Харків : Видавничий дім «Інжек», 2004. 404 с.

12. Утяшев М.М., Корнилаева А.А. Контрольные фрункции региональных парламентов: сравнительный анализ. Право и политика. Москва, 2001. № 1. C. 29-32, 30.

13. Череміскіна Н.В. Цивільний контроль над воєнною організацією держави. Нова політика. 2002. № 2. C.42-45. 